University of Nebraska - Lincoln

DigitalCommons@University of Nebraska - Lincoln

2014

Open Access Web Resources for Library Continuing Education and Training

Mary K. Bolin

University of Nebraska--Lincoln, mbolin2@unl.edu

Follow this and additional works at: https://digitalcommons.unl.edu/libraryscience

Bolin, Mary K., "Open Access Web Resources for Library Continuing Education and Training" (2014). Faculty Publications, UNL Libraries. 307.

https://digitalcommons.unl.edu/libraryscience/307

This Article is brought to you for free and open access by the Libraries at University of Nebraska-Lincoln at DigitalCommons@University of Nebraska - Lincoln. It has been accepted for inclusion in Faculty Publications, UNL Libraries by an authorized administrator of DigitalCommons@University of Nebraska - Lincoln. 


\title{
Chapter 8 \\ Open Access Web Resources for Library Continuing Education and Training
}

\author{
Mary K. Bolin \\ University of Nebraska, USA
}

\begin{abstract}
Continuing education and training are essential for a vital and productive organization and for employee adaptability and job satisfaction. Libraries of all types are organizations that value learning. Training and development for library employees is expensive, and can be out of reach for smaller institutions, or libraries that are not well-funded. Regardless of funding, libraries of all types can benefit from the wide variety of training and continuing education opportunities available on the Web as open access resources. These include documentation, journal articles, reports and white papers, online courses, videos, podcasts, and so on, from many different reliable sources. This chapter surveys major sources and types of open access online learning, and evaluates their usefulness for library employees.
\end{abstract}

\section{INTRODUCTION}

The Web has had an impact on nearly everything we do. In the past 15 years, the ways in which we communicate, shop, work, and learn have been profoundly changed by the pervasiveness of Web technologies. The effect on teaching and learning has been particularly profound. There are many online programs of instruction, in every subject and for every level and kind of student. The delivery of online instruction has become more and more sophisticated, supporting many styles and modes of teaching and learning. This can be a tremendous benefit to organizations of all kinds, who are faced with the need to continuously train and develop employees. Online training can save organizations money and can be instantly and simultaneously available to a large number of people. Such training can be self-paced and can take less time to accomplish when there is no need to travel or to

DOI: 10.4018/978-1-4666-4675-9.ch008

Copyright (c) 2014, IGI Global. Copying or distributing in print or electronic forms without written permission of IGI Global is prohibited. 
meet face-to-face as a group. Like place-bound people in every situation, employees can have learning opportunities they would not otherwise have had through the use of online education.

While it is clear that for-credit classes and programs are available, what about other kinds of learning? Librarians and library staff, like people in other workplaces and professions, need continuous learning to remain effective and to have job satisfaction. Library organizations are generally committed to providing resources for staff development, including webinars, in-person instruction from trainers or consultants, and in-house training provided by experts from within the organization. Most libraries of any size probably have some budget for staff development. In the current Web environment, however, there is a broad array of open access resources for librarians and library staff, available freely and at no cost beyond the cost of computers and Web connectivity. This chapter will survey and evaluate some of those resources to let readers know what is available, who the most prominent sources or providers are, and how to find training and learning resources that meet the needs of library employees. These resources will be evaluated in terms of their usefulness for different kinds of library employees.

This chapter surveys training and continuing education resources in different areas, including general resources (staff development for all library employees); technical services (acquisitions, cataloging, serials and electronic resources, preservation); public services (reference, instruction, user services); collection development (including special collections); information technology(IT); digital projects; and administration, supervision, and management. Resources include written texts, videos, slideshows, interactive resources, tutorials, courses, and so on. Examples have been chosen because they are from reliable and authoritative sources (well-known universities, library agencies and associations, other well-known organizations).
The material surveyed here is generally current, relevant, and appropriate to the needs of libraries.

It may not be possible to "survey" the Web in any comprehensive way. Moreover, the material presented here may be gone tomorrow or next year, although the sources chosen are generally authoritative and stable. The purpose of this chapter is not to present a list of links, but to explore the kinds of open access Web-based learning that may be helpful to individual library employees as well as library organizations.

\section{Libraries and Learning}

Twenty-first century libraries exist in an environment that is both exhilarating and challenging. Continuous rapid changes in technology make it difficult to keep ahead of the curve and make rational and strategic choices. Information technology is integral to library services and library employees must be comfortable with new technology. Because libraries need employees who can quickly acquire new skills and expertise and be ready for change, they require an organizational environment that supports learning, because an authoritarian organization is not innovative or creative. In the early 20th century, organizations, including libraries, were attracted to "scientific management," an idea made famous by Taylor (1911), who did influential studies that led to training practices. This kind of training had a goal of standardizing and routinizing work processes, and teaching the "one best way," an approach that is called "Taylorism." Taylorism retains some influence in libraries today, but libraries are fundamentally learning organizations, which support learning above every other value. Organized learning can enhance an employee's capacity to achieve the goals of the library. While focused, specific, and generally Taylorist training may still have some place in libraries and other organizations, the more important kind of learning for 
today's libraries is the exploratory, holistic, and developmental learning that makes the library forward-looking and adaptable.

The literature of organizational, staff, and professional development is vast. For much of the 20th century, theories of management, administration, performance, training, job satisfaction, and so on, multiplied and were of interest to every kind of organization, as they remain today. Libraries have a dual nature that makes them turn to these theories to balance the need to be efficient and productive with the need to think, innovate, and be engaged with users. Organizational development and learning are essential to libraries, whether it is training focused on specific skills or activities that focus on navigating change, working with communities, or using technology creatively.

There is also an interesting body of literature that discusses online learning. A lot of it focuses on distance learning, including online degree programs and for-credit education in general. The literature reviewed here focuses on approaches to professional development and specific training and knowledge for library application or more generally for IT (as well as useful skills such as language learning.)

The training and continuing education of librarians and library staff have been explored by many authors. Feldman (2007) discusses the orientation of special librarians, including the provision of online learning resources. Cooke (2012) urges librarians to stay current with continuous professional development, including developing a Personal Learning Network that can reduce the need to travel in order to learn new things. Young and Harvey (2010) discuss professional development for library media specialists, including online learning resources. Green and Cifuentes (2008) and Green (2006) compare online and face-to-face professional development with school librarians, finding that online follow-up with peer interaction had a positive effect on online professional development activities.
While there is useful literature that addresses libraries in particular, there are also lessons to be learned from other professions. Healthcare, in particular, has some of the same motives and concerns (keeping knowledge up-to-date, helping the public) as librarianship. Oduwole and Oyewumi (2010) examined use of online resources by physicians, through a portal provided at no cost by the World Health Organization. The authors found that respondents used the portal but did not have adequate time or Internet access to make the best use of it. Dodds (2011) surveys the use of distance learning in training and education of healthcare workers. McKimm and Swanwick (2010) discuss Web-based training for medical students and healthcare workers, with " 16 short, open access, free-standing modules" (52). Prottsman (2006) explores Web-based education for medical librarians. Korhonen and Lammintakenen (2005) explore the use of Web-based learning by nurse managers, finding online learning to be extremely useful in a healthcare setting. Godfrey (2006) reports on an open access site developed by a nursing specialist for other nurses and its use in cancer nursing education.

NZ Management Magazine (2001) reports on the early efforts of MIT to make course materials available on open access websites. This was an important step that was instrumental in the development of Massive Open Online Courses (MOOCs). MOOCs are open access courses that can be used for many purposes. They cover a range of topics and often have thousands of students. MOOCs are being offered by more and more institutions and are sometimes used in conventional for-credit courses as part of the learning activities. Universities are experimenting with incorporating them into their programs of study and exploring ways of giving credit for this kind of course. They are promising in a number of ways for workplace education for library staff and many other kinds of employees. Kirschner (2012) describes the author's experience with a 
MOOC and the differences between a MOOC and a conventional online course. The availability of online courses (open access and otherwise) and different forms of courseware are discussed by authors such as Bell (2012), who explores MOOCs, and the most popular platform, Coursera. Mangan (2012) explores the impact of MOOCs and similar open access courses, looking at platforms such as Coursera and Udacity and the collaboration among major institutions such as Harvard and MIT. deWaard, et al., (2011) discuss the use of MOOCs in the field of education, using the "core MOOC components of self-organization, connectedness, openness, complexity, and the resulting chaos," which can lead to a "transformative educational paradigm" (94).

Online or Web-based training is an important topic in general discussions of education, including workplace education. Ghalib, Chandrashekara, and Talawar (2009) look at opensource courseware and its use by engineering faculty. Hawkins (1997) is an early discussion of Web-based training, which explores the basic issues in online learning: equipment, access, design of instruction, etc. Matkin (2012) looks at Web-based education as a means to universal access, including alternative certification. Everley (2011) compares computer-based and Web-based training, with Web-based methods emerging as more accessible and efficient. Liebeskind (2005) describes an online safety training program that was designed for employees with limited computer experience. Kao and Tsai (2009) look at Internet self-efficacy and its relationship to Web-based learning, finding a positive correlation. Light and Stirk (2008) review two online learning sites provided by UNESCO. Minkel (2003) looks at professional development resources including online resources and training software.

Teachers have a strong need for continuing education as a certification requirement and a means of staying current and effective. Wyatt (2006) discusses the use of webinars for online learning by teachers. Smithers (2010) reviews the use of open access Web resources such as Flickr in teaching. Boehm, et al., (2012) discuss the development of a Web-based professional development program for teachers of social studies, which is "designed to complement and extend the impact of face-to-face in-service teacher training" (41). Cuthell (2008) describes online learning opportunities for K-12 teachers and students, including professional development and the needs of adult learners.

Aside from materials that are specifically designed for online learning, there is open access scholarly material on the Web that can be of use to library employees. Norris, Oppenheim, and Rowland (2008) discuss the effectiveness of Google Scholar, Google, OAIster and OpenDOAR in finding open access, peer-reviewed articles, finding different levels of effectiveness depending on the subject area.

\section{Modes of Instruction}

There is no controversy, in theory, about the need for training, education, and development in the workplace. Some organizations may lack a true commitment to it, or approach it in an ineffective or half-hearted way, but there is general agreement that it is a good and helpful thing. There is disagreement, however, about the way that training and education are delivered. There are differences among individuals, organizations, and researchers on the value and effectiveness of online education.

Price, Richardson, and Jelfs (2007) compare online instruction with a model that includes faceto-face, telephone, and email contact. Respondents reported less satisfaction with online instruction. Ryan, et al., (2007) discuss a continuing education course for medical practitioners, contrasting online and face-to-face delivery. The study showed that online instruction was as successful as the original face-to-face format.

Topper (2007) reports on research that shows that online instruction is as effective as its face-toface counterpart. Wang and Woo (2007) contrasted 
online and face-to-face discussion, finding that "atmosphere, response, efficiency, interactivity, and communication" (272) differed in the two modes of communications. Chamberlain and Taylor (2011) looked at online training for grading standard tests taken by pupils in the UK and found that online delivery was an effective and reliable method. Cowden and Sze (2012) examine teaching methods for online instruction, and found that the "lecture less, facilitate more, think more, learn more, and demand more," led to more engagement and more learning from students.

Lee, Frenzelas, and Anders (2008) discuss "blended learning," which mixes online and faceto-face instruction, and its use in the workplace. Ward (2003) discusses blended learning and the role of online learning in strengthening face-toface learning in organizations. Ashby, Sadera, and McNary (2011) looked at the results of online, face-to-face, and blended learning for community college students in a developmental math class, finding no significant difference between the three modes. Anderson and May (2010) researched delivery methods for library instruction, including face-to-face, online, and blended learning, finding support for, "an inclusive model of information literacy." Yelon (2006) describes a process for constructing blended learning, including "focus on instructional methods, assess motivation to restructure, judge the suitability of the medium for the method, and assess resources for development and delivery" (22).

Boden and Stubbings (2008) pose the question of whether librarians like online learning (since they are involved in online instruction) and describe an online course created for reference and instruction staff. Haley (2008) explores relationships among demographic variables and preference for online or face-to-face training among library employees. Results showed no correlation between preference and variables, but that online training was viewed as less effective. Brooks (2010) discusses communities of practice and their use in online discussion forums for faculty development and support, finding support for a blended model.

Wakimoto (2012) conducted a study to assess the preferred mode of library instruction among public library patrons. The study showed that patrons preferred face-to-face instruction, in small groups or individually.

$\mathrm{Yu}$ (2009) found that online discussion had a favorable effect on high school students' participation in classroom discussion, but did not improve their learning.

Gaver and Berge (2010) explored online training for employees and found that, while cost and convenience were factors in choosing online training, the employees themselves were influenced by their interest in particular topics.

\section{OPEN ACCESS ONLINE EDUCATION SOURCES: DESCRIPTION AND EVALUATION}

There are more and more sources of open access online education of all kinds. These include free universities, free courses from universities, and learning resources created by various individuals, organizations, and communities. The following are some representative sources and types of open access online education, development, and training. They are described and categorized to help libraries and library employees evaluate them with respect to learning requirements.

\section{Evaluation of Resources for Library Employees}

The Web resources described below have been evaluated as sources of training and education for library employees. The system of evaluation has been devised and carried out by the author, and is an indication of the type, format, and availability of these resources. The evaluation was 
done by examining these sites to discover the nature of their contents. The resources evaluated are selected because they are representative of the options available, and because they are from well-known and reliable sources. There are many other similar sources. The evaluation considered whether there were resources relevant to training and development needs in areas such as:

- $\quad$ Library staff development

- Library professional development

- Library metadata

- Library cataloging

- Library administration and management

- Library access services or library user services

- Library reference services

- Library instruction

- Library collection development

- IT

- Library digital initiatives

- Other (particularly language learning, general management, statistics)

Resources are evaluated using the following attributes:

1. Categories

a. Professional development (PD). Valuable knowledge for professional and paraprofessional library employees, on library-related topics as well as many others, but not directly related to job duties.

b. Staff training (ST). Valuable knowledge for professional and paraprofessional library employees, relevant to job duties but not exclusively library-related, e.g., statistics, computer programming, foreign languages.

c. Library training (LT). Valuable knowledge for professional and paraprofessional library employees, on a libraryrelated topic and directly related to job duties
2. Formats
a. $\quad$ Text (T)
b. Video (V)
c. Interactive (quizzes, tutorials, etc.) (I)
d. Slideshow (S)
e. Podcast (P)

3. Availability
a. Scheduled (S)
b. Archived (A)
- The University of the People (http://www.uopeople.org/)

Categories: PD, ST

Formats: T, V, I

Availability: $\mathrm{S}$

The University of the People was founded in 2009 and has support from the UN and a number of private universities and foundations. At this time, the only fees are $\$ 10-50$ processing fees for applications, and $\$ 100$ per examination. There are scholarships available to cover those fees. The University of the People offers a conventional online teaching and learning environment. The University of the People currently offers degree programs in business and computer science. There are no library and information science (LIS) courses, but the courses it offers are potentially very useful to librarians and other library employees. Computer science and aspects of business such as e-commerce and marketing are relevant and applicable to many library programs and services.

- Open Culture (http://www.openculture. com/freeonlinecourses)

$$
\begin{array}{ll}
\circ & \text { Categories: PD, ST } \\
\circ & \text { Formats: T, V, I } \\
\circ & \text { Availability: S, A }
\end{array}
$$

Open Culture aggregates free online courses as well as many other learning resources. There are no "library" courses listed, but there are several that are generally on "information," including an introduction to information studies and a course on the history of information. There are numerous 
courses in computer science, foreign languages, and statistics. Other courses include the arts, humanities, sciences, and social sciences, offered on iTunes, YouTube, and various Web platforms, from prominent institutions in the US and elsewhere, including the University of Michigan, MIT, Notre Dame, the University of California--Berkeley, and Oxford University.

- Open Learning (http://www.open.edu/ openlearn/)

$\begin{array}{ll}- & \text { Categories: PD, ST } \\ \circ & \text { Formats: T, V, I } \\ \circ & \text { Availability: S, A }\end{array}$

The Open University is not tuition-free, but it has an open access component called "Open Learning" with a large number of free online short courses, lectures, and tutorials on many different topics. These are delivered primarily as text or video. Open Learning provides a variety of interesting courses, tutorials, and other material. Some are as short as five minutes. There is almost no material on LIS topics (one unit on a book talk for children), but there is a great deal of material on IT, including a unit that takes 50 hours and covers a range of IT skills. There are also substantial resources for language learning and many aspects of management and statistics.

- $\quad$ Coursera (https://www.coursera.org/)

$\begin{array}{ll}\circ & \text { Categories: PD, ST, LT } \\ \circ & \text { Formats: T, V, I, S, P } \\ \circ & \text { Availability: S }\end{array}$

Coursera is the platform for MOOCs on many topics and from many different institutions. Coursera invites users to "take the world's best courses. Online. For free." Participating institutions include Columbia University, Johns Hopkins, Stanford, and a number of others. Courses cover a range of topics, including math, science, psychology, writing, etc. Coursera offers MOOCs that are asynchronous but which have a specific period during which they take place, generally six to ten weeks.

There are a few LIS courses, including one on metadata from the University of North Carolina, Chapel Hill, as well as courses on management, statistics, and IT. The courses include text, audio, video, and other delivery formats.

- Udacity (https://www.udacity.com/)

$$
\begin{array}{ll}
- & \text { Categories: PD, ST } \\
\circ & \text { Formats: T, V, I, P } \\
\circ & \text { Availability: S, A }
\end{array}
$$

Udacity is a MOOC platform, offering courses in business, math, computer science, and statistics. Udacity's approach is that "the lecture is dead," and learning is interactive and "bite-sized." Udacity offers a small number of courses on business, computer science, mathematics, and physics. These are not aimed at libraries, but could be useful nevertheless. Like other MOOCs, these include text, audio, and video.

- Class Central (http://www.class-central. $\mathrm{com} /$ )

$$
\begin{array}{ll}
\text { - } & \text { Categories: PD, ST } \\
\circ & \text { Formats: T, V, I, P } \\
\circ & \text { Availability: S, A }
\end{array}
$$

Class Central is a "MOOC aggregator" that lists upcoming MOOCs from many different universities on a number of platforms. The courses cover a wide range of topics, including art appreciation, film studies, math, computer science, and business.

- The Idaho Commission for ABLE (Alternative Basic Library Education) (http://libraries.idaho.gov/page/able)

\footnotetext{
- Categories: LT

- Formats: T

- Availability: A
} 
The Idaho Commission for Libraries has an online education program for library employees called "ABLE" (Alternative Basic Library Education). It includes sequences on collection development, technical services, and public services, and is aimed at library employees who need an introduction to the fundamentals of library service. The courses are text-based and self-directed and have about six hours of instruction apiece.

- Arizona State Library (http://www.azlibrary.gov/extension/continuing_education.aspx)

\section{- Categories: LT \\ - Formats: T \\ - Availability: A}

The Arizona State Library provides various kinds of training, but provides open access Webbased training in collection development. It is self-paced and text-based

- WebJunction (http://www.webjunction. org/)

$\begin{array}{ll}- & \text { Categories: LT } \\ \circ & \text { Formats: T } \\ \circ & \text { Availability: A }\end{array}$

WebJunction is "the learning place for libraries." Its mission is to "promote learning for all library staff by providing an open, affordable online learning community." (http://www.webjunction.org/about-us.html) WebJunction has several hundred self-paced Web courses, which are free to employees who are sponsored by state library organizations that have partnered with OCLC/ WebJunction for this purpose. WebJunction also provides a large archive of documentation, webinars, slide shows, and other resources on a wide spectrum of library topics, such as budgeting, leadership, management, collection development, and programming of all kinds.

- Library of Congress (http://www.loc.gov/ standards/)

- Categories: PD, LT

- Formats: T, $\mathrm{S}$

- Availability: A

The Library of Congress maintains a number of metadata standards and has substantial documentation on those standards, which can used to learn about them and to plan and implement metadata projects

- Cataloger's Learning Workshop (http:// www.loc.gov/catworkshop/courses/index. html)

- Categories: PD, LT

- Formats: T, $\mathrm{S}$

- Availability: A

The Library of Congress Cataloger's Learning Workshop has slideshows from its metadata courses. These are long and detailed, and can be used by individuals or groups to learn about many topics in cataloging and metadata.

- Jisc (http://www.jisc.ac.uk/)

- Categories: PD

- Formats: T

- Availability: A

Jisc (http://www.jisc.ac.uk/) is a UK organization that "[works] on behalf of UK higher education, further education and skills to champion the use of digital technologies." Jisc offers training and consulting on a range of topics to organizations in the UK. Its website has hundreds of useful 
documents on topics like digital libraries, resource discovery, lifelong learning, and many more.

- UKOLN (http://www.ukoln.ac.uk/)

$\begin{array}{ll}\text { - } & \text { Categories: PD } \\ \text { - Formats: T, S } \\ \text { - Availability: A }\end{array}$

UKOLN (http://www.ukoln.ac.uk/) is similar to Jisc, and its website includes many resources useful for continuing education and training, including the journal Ariadne, and documentation and reports on numerous projects that include metadata schemes and institutional repositories, as well as publications, presentations, and tutorials on topics such as data curation, digital repositories, metadata, discovery tools, and many others.

- $\quad$ World Wide Web Consortium (W3C) W3C Schools (http://www.w3schools.com/default.asp)

\section{- $\quad$ Categories: PD, ST \\ - Formats: T, I \\ - Availability: A}

The World Wide Web Consortium (W3C) provides an enormous amount of open access learning on XML and other crucial topics, especially via their "W3C Schools." Individuals can learn HTML, XML, PHP, CSS, RDF, and many other languages and tools, and can earn W3C certification.

- Dublin Core Metadata Initiative (DCMI) (http://dublincore.org/)

- Categories: PD, ST, LT

- Formats: T, $\mathrm{S}$

- Availability: A
The Dublin Core Metadata Initiative (DCMI) provides a huge archive of standards, documentation, and examples that can serve as an indispensable resource for Dublin Core applications. Resources include archived webinars and presentations, documentation, and links to papers presented at the yearly international Dublin Core conference.

- $\quad$ OCLC Research (http://www.oclc.org/research.html)

$$
\begin{array}{ll}
\circ & \text { Categories: PD } \\
\circ & \text { Formats: T } \\
\circ & \text { Availability: A }
\end{array}
$$

OCLC Research is a source for reports on emerging issues of interest to library employees, including the assessment of collections, digitization products, cataloging and metadata, Web 2.0 applications, and digital libraries

- Council on Library and Information Resources (CLIR) (http://www.clir.org/ pubs/pubs.html)

$$
\begin{array}{ll}
\circ & \text { Categories: PD } \\
\circ & \text { Formats: T, P } \\
\circ & \text { Availability: A }
\end{array}
$$

CLIR has information on many different topics, including research libraries, digitization, library assessment, and reports on CLIR projects and initiatives.

- Coalition for Networked Information (CNI) (http://www.cni.org/)

\footnotetext{
- Categories: PD

- Formats: T, S, P

- Availability: A
} 
CNI has material on scholarly communication and other topics related to the use of digital information for research and scholarship.

- $\quad$ EDUCAUSE (http://www.educause.edu/)

- Categories: PD, ST, LT

- Formats: T, V, I, S, P

- Availability: A

EDUCAUSE provides information of interest to universities, including academic libraries. Topics include cybersecurity, ebooks, library administration, information literacy, and information retrieval.

- American Library Association (ALA) (http://www.ala.org/tools/atoz)

- $\quad$ Categories: PD, ST, LT

- Formats: T

- Availability: A

ALA offers workshops and courses that are not free or open access, but its site also provides policies, guidelines, and standards in all areas of librarianship, including library types (academic, public, school) and library programs and services (acquisitions, cataloging, collection development, management and administration, reference and instruction, and user services.)

- $\quad$ Slideshare (http://www.slideshare.net/)

- Categories: PD, ST, LT

- Formats: T, V, S, P

- Availability: A

Resources that are specifically created for library employees may still have valuable learning resources. Slideshare is an open access repository of slideshows from presentations, conferences, and meetings of all kinds. It includes presentations on every imaginable topic that might be of interest to librarians, including reference, instruction, cataloging, access services, administration, and so on. The presentations are from around the globe and include videos, narrated slideshows, slides without notes or narration, and other kinds of documents. There are many library-related presentations on every library type and library service.

- YouTube (http://www.youtube.com/)

$\begin{array}{ll}\text { - } & \text { Categories: PD, ST, LT } \\ \circ & \text { Formats: V, S } \\ \circ & \text { Availability: A }\end{array}$

Along with its entertainment function, YouTube has a strong educational role, with many previously-mentioned MOOCs and other online courses using this platform. In addition, there are videos and slideshows from individuals and organizations, including libraries and librarians. Like Slideshare, YouTube has material for all library types and library functions. It includes many videos on a range of topics for continuing education, training, and professional development. These are provided by individual librarians, associations like ALA, libraries, universities, and other organizations

- Registry of Open Access Repositories (ROAR) (http://roar.eprints.org/)

$\begin{array}{ll}\circ & \text { Categories: PD, ST, LT } \\ \circ & \text { Formats: T, V, I, S, P } \\ \circ & \text { Availability: A }\end{array}$

Institutional repositories have had a revolutionary effect on scholarly communication in the last 10 years. The Registry of Open Access Repositories (ROAR) lists hundreds of repositories and gives access to thousands of documents and other media such as images. ROAR's interface is not easy to use to find documents or learning objects, but 
it can be used to identify repositories of theses, learning material such as tutorials, videos, texts, and so on, which can be found most easily by searching individual repositories.

- OAISTER (http://oaister.worldcat.org/)

$\begin{array}{ll}\circ & \text { Categories: PD, ST, LT } \\ \circ & \text { Formats: T, V, I, S, P } \\ \circ & \text { Availability: A }\end{array}$

OAISTER is a repository of open archives that is housed by OCLC. Its search interface retrieves open access material of all kinds, including articles, ebooks, dissertations, images, videos, and so on. It contains material on a variety of LIS topics.

- State Libraries:

$\begin{array}{ll}\circ & \text { Categories: LT } \\ \circ & \text { Formats: T, V, I, S, P } \\ \circ & \text { Availability: S, A }\end{array}$

State libraries and library agencies offer open access training materials on topics such as computer literacy, management and supervision, library instruction, collection development, and so on. Some material may only be available to the residents of the state.

Examples:

- Colorado (http://www.cde.state.co.us/ cdelib/CE.htm)

- Vermont (http://libraries.vermont.gov/ libraries/ce/onlineopportunities)

- Kentucky (http://kdla.ky.gov/librarians/ staffdevelopment/Pages/continuingEducation.aspx)

- Nebraska (http://nlc.nebraska.gov/CE/)

- Montana (http://www.webjunction.org/ documents/montana/MTdocument38. html)

- $\quad$ Directory of Open Access Journals (DOAJ) (http://www.doaj.org)

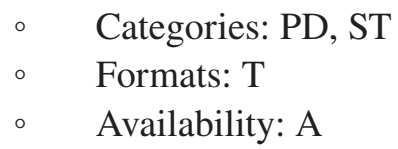

The Directory of Open Access Journals (DOAJ) aggregates open access journals and their contents. It is an international collection that includes journals from every subject area, in English and in other languages. It includes 137 journals specifically categorized as "Library and Information Science." Journals can be searched individually, and can be browsed by title or subject. Topics can be search across all journals, or in a particular journal or particular topic. There are articles on the full range of LIS topics, in English and other languages.

- $\quad$ TPOT (http://tpot.ucsd.edu/)

$\begin{array}{ll}\circ & \text { Categories: PD, LT } \\ \circ & \text { Formats: T } \\ \circ & \text { Availability: A }\end{array}$

TPOT (http://tpot.ucsd.edu/) and similar sites have documentation and links that provide a view of how one library or library system does things. These sites can be useful and interesting to staff in other libraries as well, and can be a source of training and development. TPOT was created for the employees of one university library system, but it is an open access resource that can be used in any library. It is the modern incarnation of the "department manual" that include policies, procedures, and reference material. It describes itself as serving "metadata services documentation needs," which includes links to important national and international standards and studies and local procedures that could be adapted by others.

\section{Solutions and Recommendations}

There is a lot of research that explores the effectiveness of online instruction. This delivery mode is clearly here to stay and clearly useful in many 
contexts and for many people. Moreover, the use of Internet resources of all kinds is part of the daily lives of millions of people, and certainly of most library employees. The resources evaluated for this chapter demonstrate that there is plentiful high-quality open access Web-based learning available, and a great deal of material in various formats that can be useful to library employees.

Libraries need a flexible and educated workforce, and employees who are willing and able to learn continuously. Open access resources can supply training in information, technology, metadata, user services, collection development, and so on, as well as things like language learning, management and administration, planning, and budgeting.

The recommendations below are based on examination of the sites that have been described and evaluated in this chapter, as well as the review of the literature on workplace and online learning, as well as the author's experience as a library administrator.

Recommendations for choosing open access resources:

- The most directly relevant material for libraries is found in sources like state library websites, open access journals, open access repositories, and sites like DCMI or the Library of Congress, which are dedicated to libraries or to topics like metadata.

- There is plentiful open access instruction on useful topics like statistics, computer science and web applications, budgeting and planning, and so on, on sites that offer MOOCs and other forms of free online instruction.

- There are thousands of slideshows and videos on every imaginable LIS topic and on other related and relevant topics.
- There are large repositories of reports and other documents on the sites of research and funding agencies in the US, UK, and elsewhere.

Recommendations for using these resources:

- Establish a culture of learning in the library organization, in which all employees are expected to learn, grow, and take advantage of professional development opportunities.

- Give employees "permission" to explore material that would have general or specific relevance to their jobs, and define "relevance" broadly.

- Consider open access resources in all discussions of professional and staff development.

- Consider learning styles when choosing or recommending open access material. Some people prefer text, while others learn by listening or are visual learners. Include active learning opportunities as well.

- Consider the social aspects of the Web also. Learning can occur through social media such as Facebook and other kinds of collaborative online spaces.

- Consider sharing your own documents, presentations, workshops, and tutorials on sites like Slideshare.

\section{CONCLUSION}

ACRL Planning and Review Committee (2012) lists the top ten current and future trends for academic libraries. These include programs and services such as data curation, digital preservation, and patron-driven acquisition, among other things. 
Staffing needs are also addressed, including the assertion that, "Continuing education, professional development, strategic and creative approaches to hiring for vacant or new positions, retooling existing positions, and retraining the staff currently in those positions are some of the ways libraries can 'grow' the staff they need. Data curation, digital resource management and preservation, assessment, scholarly communication, and support for faculty instruction and student learning are growth areas where new skill sets are needed" (315-316). A successful future for academic libraries requires employees who embrace learning and an organization that provides multiple opportunities to do so easily. MOOCs and other independent and self-paced learning resources are crucial for the learning culture in academic libraries.

The literature reviewed here demonstrates that online learning takes many forms, and that it is increasingly widespread and has been used successfully in different kinds of organizations. The use and effectiveness of online learning in libraries have been explored by Young and Harvey (2010), Green and Cifuentes (2008), and Green (2006). Similarly, Oduwole and Oyewumi (2010), Dodds (2011), McKimm and Swanwick (2010), Prottsman (2006), Korhonen and Lammintakenen (2005), and Godfrey (2006) found a variety of successful approaches to online learning in a healthcare setting. Numerous other studies have looked at online education, including MOOCs, in the workplace and for personal, professional, or scholarly enrichment.

Libraries of all types have a constant need for training and development of librarians and other employees. Continuous learning allows organizations to grow, adapt, and innovate. It is also expensive and time-consuming. Open access resources can save time and money by providing material that is available to everyone, as individuals or in groups. Some of the courses discussed here are offered during specific time periods. Other material is continuously available and can be used at any time. There is material for every learning style, including texts, videos, podcasts, interactive material, slideshows, etc.

Libraries should take advantage of this material, which will continue to grow. Using open access resources will allow nearly any library to make a real commitment to staff development, and will allow individual library employees to pursue many different kinds of learning. This will make them more valuable as employees and should increase job satisfaction as well.

\section{REFERENCES}

Anderson, K., \& May, F. A. (2010). Does the method of instruction matter? An experimental examination of information literacy instruction in the online, blended, and face-to-face classrooms. Journal of Academic Librarianship, 36(6), 495500. doi:10.1016/j.acalib.2010.08.005.

Ashby, J., Sadera, W., \& McNary, S. (2011). Comparing student success between developmental math courses offered online, blended, and faceto-face. Journal of Interactive Online Learning, 10(3), 128-140.

Bell, M. (2012). Massive open online courses. Internet@Schools, 19(5),23-25.

Boden, D., \& Stubbings, R. (2008). Do librarians like to learn online? In IFLA Conference Proceedings, 1-15.

Boehm, R., Brysch, C., Mohan, A., \& Backler, A. (2012). A new pathway: Video-based professional development in geography. The Journal of Geography, 111(1-2), 41-53. doi:10.1080/00221 341.2011.584068.

Brooks, C.F. (2010). Toward “hybridized" faculty development for the twenty-first century: Blending online communities of practice and face-to-face meetings in instructional and professional support programmes. Innovations in Education and Teaching International, 47(3), 261-270. doi:10. 1080/14703297.2010.498177. 
Chamberlain, S., \& Taylor, R. (2011). Online or face-to-face? An experimental study of examiner training. British Journal of Educational Technology, 42(4), 665-675. doi:10.1111/j.14678535.2010.01062.x.

Cooke, N. A. (2012). Professional development 2.0 for librarians: Developing an online personal learning network (PLN). Library Hi Tech News, 29(3), 1-9. doi: doi:10.1108/07419051211241840.

Cowden, P., \& Sze, S. (2012). Online learning: The concept of less is more. Allied Academies International Conference: Proceedings of the Academy of Information \& Management Sciences (AIMS), 16(2), 1-6.

Cuthell, J. P. (2008). Online forums as a resource for teacher professional development: Lessons from a web-based community of practice and influence. International Journal of Web Based Communities, 4(3), 7. doi:10.1504/IJWBC.2008.019195.

deWaard, I., Abajian, S., Gallagher, M., Hogue, R., Keskin, N., Koutropoulos, A., \& Rodriguez, O. C. (2011). Using mLearning and MOOCs to understand chaos, emergence, and complexity in education. International Review of Research in Open and Distance Learning, 12(7), 94-115.

Dodds, T. (2011). Open and distance learning for health: Supporting health workers through education and training. Open Learning, 26(2), 173-179. doi: doi:10.1080/02680513.2011.567757.

Everley, M. (2011). Training methods. Rospa Occupational Safety \& Health Journal, 41 (9), 29-32.

Feldman, A. (2007). Who's the best person to show new employees the ropes? Information professionals - as employee guides - can make the difference between entering the workplace on the fast track or through back-alley detours. Information Outlook, 11(5), 47.
Gaver, J., \& Berge, Z. (2010). The role subject matter plays in the decision to offer online training. Distance Learning, 7(1), 49-56.

Ghalib, M. A. M., Shekara, C., \& Talawar, V. G. (2009). Awareness and extent of utilisation of Webbased open source e-learning coursewares among educators and students. DESIDOC Journal of Library \& Information Technology, 29(3), 43-48.

Godfrey, K. (2006). Cancer nursing education online. Australian Nursing Journal, 14(5), 17.

Green, M. (2006). An investigation of online environments supporting follow-up to professional development for Texas schoollibrarians. (Doctoral dissertation, University of North Texas). Retrieved from Dissertation Abstracts International Section A, 66.

Green, M., \& Cifuentes, L. (2008). An exploration of online environments supporting follow-up to face-to-face professional development. Journal of Technology and Teacher Education, 16(3), 283-306.

Haley, C. K. (2008). Online Workplace Training in Libraries. Information Technology \& Libraries, 27(1), 33-40.

Hawkins, D. T. (1997). Web-based training for online retrieval: An idea whose time is coming. Online, 21, 68-69.

Kao, C., \& Tsai, C. (2009). Teachers' attitudes toward web-based professional development, with relation to Internet self-efficacy and beliefs about web-based learning. Computers \& Education, 53(1), 66-73. doi:10.1016/j.compedu.2008.12.019.

Kirschner, A. (2012). A pioneer in online education tries a MOOC. The Chronicle of Higher Education, 59(6), B21-B22. 
Korhonen, T., \& Lammintakanen, J. (2005). Web-based learning in professional development: Experiences of Finnish nurse managers. Journal of Nursing Management, 13(6), 500-507.doi:10.1111/j.1365-2934.2005.00556.x PMID:16238691.

Lee, D., Frenzelas, G., \& Anders, C. (2008). Blended learning for employee training: Influencing factors and important considerations. International Journal of Instructional Media, 35(4), 363-372.

Liebeskind, K. (2005). With open arms. Occupational Health \& Safety (Waco, Tex.), 74(11), 72. PMID:16355590.

Light, K., \& Stirk, L. (2008). Open access training material. Journal of Health Services Research \& Policy, 13(3), 192. doi:10.1258/ jhsrp.2008.008044.

Management Magazine, N. Z. (2001). Web learning for free. New Zealand Management, 48(4), 9.

Mangan, K. (2012). MOOC mania. The Chronicle of Higher Education, 59(6), B4-B5.

Matkin, G. (2012). The opening of higher education. Change, 44(3), 6-13. doi:10.1080/0009138 3.2012.672885.

McKimm, J., \& Swanwick, T. (2010). Webbased faculty development: E-learning for clinical teachers in the London Deanery. The ClinicalTeacher, 7(1), 58-62.doi:10.1111/j.1743498X.2009.00344.x PMID:21134145.

Minkel, W. (2003). Professional development tools you can use. School Library Journal, 49(2), 10.

Norris, M., Oppenheim, C., \& Rowland, F. (2008). Finding open access articles using Google, Google Scholar, OAIster and OpenDOAR. Online Information Review, 32(6), 709-715. doi:10.1108/14684520810923881.
Oduwole, A., \& Oyewumi, O. (2010). Accessibility and use of Web-based electronic resources by physicians in a psychiatric institution in Nigeria. Program: Electronic Library \& Information Systems, 44(2), 109-121. doi:10.1108/00330331011039472.

Planning, A. C. R. L.Review Committee. (2012). 2012 top ten trends in academic libraries: A review of the trends and issues affecting academic libraries in higher education. College \& Research Libraries News, 73(6), 311-320. Retrieved from http://crln.acrl.org/content/73/6/311.full.

Price, L., Richardson, J. E., \& Jelfs, A. (2007). Face-to-face versus online tutoring support in distance education. Studies in Higher Education, 32(1), 1-20. doi:10.1080/03075070601004366.

Prottsman, M. (2006). Professional development. Journal of Hospital Librarianship, 6(1), 115-120. doi:10.1300/J186v06n01_12.

Ryan, G., Lyon, P., Kumar, K., Bell, J., Barnet, S., $\&$ Shaw, T. (2007). Online CME: An effective alternative to face-to-face delivery. Medical Teacher, 29(8),251-257.doi:10.1080/01421590701551698 PMID:18236269.

Smithers, M. (2010). My favourite (free) resources. Training \& Development in Australia, 37(5), 036.

Taylor, F. W. (1911). The principles of scientific management. London: Harper.

Topper, A. (2007). Are they the same? Comparing the instructional quality of online and face-toface graduate education courses. Assessment \& Evaluation in Higher Education, 32(6), 681-691. doi:10.1080/02602930601117233.

Wakimoto, D. K. (2012). Public library clients prefer formal classes for initial training on library's online resources and informal, on-demand assistance for further training. Evidence Based Library \& Information Practice, 7(1), 105-107. 
Wang, W., \& Woo, H. L. (2007). Comparing asynchronous online discussions and face-to-face discussions in a classroom setting. British Journal of Educational Technology, 38(2), 272-286. doi:10.1111/j.1467-8535.2006.00621.x.

Ward, J. (2003). Blended learning: The convergence of e-learning and meetings. Franchising World, 35(4), 22-23.

Wyatt, E. (2006). Webinar series for school librarians: Case study of online professional development. Illinois Libraries, 86(3), 20-21.

Yelon, S. (2006). Face-to-face or online? Choosing the medium in blended training. Performance Improvement, 45(3), 22-26. doi:10.1002/ pfi.2006.4930450306.

Young, T., \& Harvey, C. (2010). Professional development on a shoestring. School Library Monthly, 26(6), 18-21.

Yu, S. W. (2009). The impact of online discussion on face-to-face discussion and academic achievement. American Secondary Education, $37(2), 4-25$.

\section{ADDITIONAL READING}

Aden, L. A. P. (2010). Effects of learning styles on online professional development with educators. (Doctoral dissertation, Walden University). Retrieved from ProQuest Dissertations and Theses, 239.

Alwadie, A.D. (2011). An assessment of the readiness of King Fahad Medical City, Saudi Arabia, in adopting effective online staff development programs. (Doctoral dissertation, Wayne State University). Retrieved from: ProQuest Dissertations and Theses, 127.
Attwell, G. (2007). Personal Learning Environments-the future of eLearning? ELearning Papers, 2(1), 1-7.

Bartley, S. J., \& Golek, J. H. (2004). Evaluating the cost effectiveness of online and face-to-face instruction. Journal of Educational Technology \& Society, 7(4), 167-175.

Boeninger, C. F. (2013). Using online video for staff training. In A. Stewart, C. Washington-Hoagland, \& C. T. Zsulya (Eds.), Staff development: A practical guide (4th ed.). Chicago: American Library Association.

Bonk, C., Kim, K. J., \& Zeng, T. (2005). Future directions of blended learning in higher education and workplace learning settings. In World Conference on EducationalMultimedia, Hypermedia and Telecommunications, (pp. 3644-3649).

Bonk, C. J., \& Zhang, K. (2006). Introducing the R2D2 model: Online learning for the diverse learners of this world. Distance Education, 27(2), 249-264. doi:10.1080/01587910600789670.

Burge, E. J. (2007). Flexible higher education international pioneers reflect. Maidenhead, NY: Society for Research into Higher Education \& Open University Press.

Caswell, T., Henson, S., Jensen, M., \& Wiley, D. (2008). Open content and open educational resources: Enabling universal education. International Review of Research in Open and Distance Learning, 9(1).

Dalston, T. (2009). Evaluating e-training for public library staff: A quasi-experimental investigation. (Doctoral dissertation, University of North Texas). Retrieved from ProQuest Dissertations and Theses, 353.

Edwards, R.(1997). Changing places? Flexibility, lifelong learning, and a learning society. London: Routledge. doi:10.4324/9780203277454. 
Gatta, M. L., \& McCabe, K. P. (2005). Not just getting by: The new era of flexible workforce development. Lanham, MD: Lexington Books.

Goodwin, M. A. L. (2011). The open course library: Using open educational resources to improve community college access. (Doctoral dissertation, Washington State University). Retrieved from ProQuest Dissertations and Theses, 170.

Harry, K. (1999). Higher education through open and distance learning. London: Routledge.

Harun, M. H. (2001). Integrating e-learning into the workplace. The Internet and Higher Education, 4(3), 301-310. doi:10.1016/S10967516(01)00073-2.

Iiyoshi, T., \& Vijay Kumar, M. S. (2008). Opening up education: The collective advancement of education through open technology, open content, and open knowledge. Cambridge, MA: MIT Press.

Inoue, Y. (2007). Online education for lifelong learning. Hershey, PA: IGI Global. doi:10.4018/978-1-59904-319-7.

Jakupec, V., \& Garrick, J. (2000). Flexible learning, human resource, and organisational development: Putting theory to work. London: Routledge.

Khan, B. H. (2007). Flexible learning in an information society. Hershey, PA: IGI Global.

Khosrowpour, M. (2002). Web-based instructional learning. Hershey, PA: IGI Global.

Latchem, C. R., \& Lockwood, F. (1998). Staff development in open and flexible learning. London: Routledge.

Maeroff, G. I. (2003). A classroom of one: How online learning is changing our schools and colleges. New York: Palgrave Macmillan.
Meyer, K. A. (2002). Quality in distance education: Focus on on-line learning. San Francisco: Jossey-Bass.

Perraton, H. D. (2000). Open and distance learning in the developing world. London: Routledge.

Perraton, H. D., \& Lentell, H. (2004). Policy for open and distance learning. London: Routledge Falmer. doi:10.4324/9780203464403.

Scarsbrook, A. F., Graham, R. N. J., \& Perriss, R. W. (2005). The scope of educational resources for radiologists on the internet. Clinical Radiology, 60(5), 524-530. doi:10.1016/j.crad.2005.01.004 PMID:15851038.

Smallwood, C., Harrod, K., \& Gubnitskaia, V. (2013). Continuing education for librarians: Essays on career improvement through classes, workshops, conferences and more. Jefferson, NC: McFarland \& Company, Inc..

Stacey, E., Smith, P. J., \& Barty, K. (2004). Adult learners in the workplace: Online learning and communities of practice. Distance Education, 25(1), 107-123. doi:10.1080/01587910420002 12486

Strother, J. B. (2002). An assessment of the effectiveness of e-learning in corporate training programs. International Review of Research in Open and Distance Learning, 3(1).

\section{KEY TERMS AND DEFINITIONS}

Learning Object: A component of instruction such as a lecture, tutorial, quiz, or other activity, in a format such as text, audio, video, etc.

Learning Organization: A model of organizational development in which people learn 
together and apply that learning for the good of individuals and the organization.

Massive Open Online Course (MOOC): A course provided via open courseware such as Coursera. MOOCs are often offered by prominent faculty from well-known universities, and may have thousands of students at a time. They may be offered continuously or for a specific period of time.

Online Learning: Learning offered through Web-based resources such as texts, slideshows, videos, podcasts, and interactive learning objects. "Computer-based" training is an older model of online learning, in which learning objects are not available on the Web, but are contained in software or a similarly local means of access.

Open Access: Web-based material that is freely available. Open access resources include journals, books, and learning objects.

Professional Development: Activities, including learning activities, which encourage growth in expertise and maturity of a person who belongs to a particular profession.

Staff Development: Learning activities provided by an organization for the acquisition of new skills and general growth by employees. 